\title{
THE EFFECTIVENESS OF USING JOLLY PHONICS BLENDING PHONEMES TO YEAR 3 ENGLISH LANGUAGE CLASSROOM
}

\author{
Zulkifli Ahmad ${ }^{1}$ \\ Faculty of Education, Universiti Kebangsaan Malaysia (UKM), Malaysia. \\ (Email: zulkifli@gmail.com) \\ Melor Md Yunus ${ }^{2}$ \\ Faculty of Education, Universiti Kebangsaan Malaysia (UKM), Malaysia. \\ (Email: melor@ukm.my)
}

Received date: $18-04-2019$

Revised date: $27-08-2019$

Accepted date: 18-11-2019

Published date: 15-12-2019

To cite this document: Ahmad, Z., \& Md Yunus, M. (2019). The Effectiveness of Using Jolly Phonics Blending Phonemes to Year 3 English Language Classroom. International Journal of Humanities, Philosophy and Language, 2(8), 150-162.

DOI: $10.35631 / \mathrm{ijhpl} .280011$

\begin{abstract}
Poor word identifying skill has become an issue among weak students in the education system. Students with good skill of able to identifying words at glance are able to develop and improve their overall reading performance across subjects in the school compared to the weak students who has poor word identifying skill. This problem has not only brought a temporary halt to teachers to teach but also to students to understand any information or tasks transmitted through the teaching and learning process. In the process of word identifying skill, students must be able to recognize the sounds of letters which are phonemes that form a word. For that reason, the purpose of this study is to evaluate the effectiveness of using Jolly Phonics Blending Phonemes to 30 pupils of the Year 3 EL learners. This study uses the mix-mode method that uses the quantitative and qualitative research method to analysed the effect of the Jolly Phonics Blending Phonemes to the experimental group and the control group in the same school in six months. The findings have discovered that the experimental group had showed an overall increase in scores and interest towards the phonics teaching compared the control group that uses the traditional method of teaching phonics. The introduction of Jolly Phonics Blending Phonemes does affect the performance among the poor learners in the Year 3 EL classroom.
\end{abstract}

Keywords: Jolly Phonics Blending Phonemes, Phonics Instructions, Literacy Skills, Decode Letter Sound, Language Strategy

\section{Introduction}

Since the early youth of children until they developed the ability to speak in normal manner, they first have to learn to decode the letter sounds into words. These skills are developed 
through various stages and each stage builds their vocabulary in their minds and eventually gain the ability the speak properly. However, according to Amanda (2017), not all children are raised in such advantage of already develop literacy skill. These children have to deal with the disabilities of not able to recognize letter sounds and printed words in the early years of child development. Therefore, phonics instructions should be implemented at this early stage because, when children have developed the ability to identify and recognize letter sounds, then reading would be second nature to them. Reading habits should be instilled at a very early age by doing a lot of activities that promotes reading (Lim, Melor \& Mohamed Amin Embi, 2017). At this early age, educators need to introduce the sounds of letters as it is applicable to their current needs (Amanda, 2017). The purpose of teaching phonics is to give the children the key to knowledge and useful skills that ensure they are able to apply them to reading and writing skills (Masello, 2014). The phonics skill is a bottom-up approach that require the learners to first learn the basic skill of identifying letter sounds to text that most low literacy learners are comfortable with (Rabindra, 2016). This was agreed by Glazzard (2017) as English language learners learns to identify phonemes as a bottom- up approach of learning phonics. The studies of sounds or a group of sounds on the smallest units of sounds and phonemes is called phonology is a component of the human language (Hammond, 2016). The ability to access and manipulate these sound elements, known as phonological awareness, has always been linked to the acquisition of reading (Megan,2016). However, when reading certain printed text, not all words are spelled as same as they are sounded and young learners who can be slow learners need to adapt this to their levels which is discouraging (Rachel, 2016). This research focuses on the problems faced by educators in teaching students to recognize phonemes with the introduction of Jolly Phonics Blending Phonemes in their teaching and its effectiveness to the Year 3 pupils. Since phonics teaching is new to English teachers in Malaysia, it is important to understand that a study focusing on teaching phonics for Year 1 students should be carried out (Nadiah, 2015). Nadiah (2015) further explained that phonics teaching is an innovation in the curriculum that replaces the entire language approach used to teach reading skills in the old curriculum. The school, teachers and principal must be very aware of the different interventions to educate the child in understanding reading and developing literacy when a pupil enters the schooling level. Numerous observations conducted discovered that many Malaysian English language teachers encounter similar challenges in teaching English language where the students do not master reading skill (Antonia, Melor \& Azlina, 2016). Furthermore, those students who struggle with reading, need extra attention as it is essential during the very first years of education (Antilla, 2013).

\section{The Context and Purpose of The Study}

As the teaching of phonics is new to English educators in Malaysia, it is vital to learn that further studies should be focuses on the instructions of phonics to Year 1 (Nadiah, 2015). She also explained that the teaching of phonics is a teaching method that brought about the changes in the curriculum as a complete language strategy used for the teaching of reading competencies. If children come into the school faculty and bearing with them no prior experiences with reading, the school administrators and teachers need to be very conscious with interventions that can be used to train the children in the literacy development (Antilla, 2013). Extra effort and assist are a necessity for these young learners who are struggling with reading at some point of the very first years of schooling (Antilla, 2013). Consequently, a new method is purposed to overcome such problem at the early level of teaching the English Language. This study is to evaluate the effectiveness of the usage of Jolly Phonics Blending Phonemes to the Year 3 English Language Classroom students. This study will be focus on the 30 pupils in the EL classroom that have reading difficulties. Jolly Phonics involves the decoding sighted letters that makes different sounds that blends together to form recognizable 
and understandable words that provide meanings. This skill requires the pupils to have the skills to decode letter sound that they use easily or by their own and thus enable the pupils' ability to use that skill to read printed words. Reading is the skill of decoding and identifying written texts. Decoding requires translating the symbols of sounds of letters into the spoken phrases that can be understood (Amanda, 2017). By learning the Jolly Phonics method and blend phonemes to make up words, it is expected that the children can understand and identify the meaning of new words and by knowing these correlations will help the pupils to recognize unfamiliar phrases and spontaneously able to decode new words with less guidance at some point of the learning process (Masello, 2014). Reading can be successful of the reader can actually understand what is read (Olviyanti, 2015). In other words, the primary advantages of reading are the positive attitude towards education. It is when a learner is able to read properly and fluently, there won't be any problem dealing with other subjects in the school (Nasrawi, 2017). It is come to this that this study intends to answer the following research questions:

1. How will the Year 3 Primary EL pupils improve the ability to identify different types of letter sounds when using the Jolly Phonics Blending Phonemes method?

2. How would the Jolly Phonics Blending Phonemes increase the interest of the Year 3 Primary EL students in learning Phonics?

\section{Literature review}

\section{The Phonics Instructions}

It is vital and essential for the pupils to have the ability to read. It is necessary for these pupils to have a practical method of learning to read (Kellie, 2013). Particularly as establishing readers, a more structured and extra intensive intervention should be implemented to these group of learners as standardized approach of phonics teaching had proved more successful based on previous research (Buckingham,2013; Lonigan, 2013). As a result, learning phonics helps the new learners to read and write quickly as they progress Nasrawi, 2017). Moreover, the traditional method of recognizing words by spelling should also change to the phonetic reading system (Sharipah, 2015). Sharipah also explained that the traditional way of teaching takes longer time when mastering the reading skill and thus reduce the stress of leaning by memorizing words. It was found that spelling words and reading simple sentences has become the main issues of children are having problem with reading difficulties and when coping with this situation, children will experience to many thinking processes at a time. In facing this problem, the educators need to understand to the five levels of difficulties which include the phonological and phonemic awareness, phonics decoding, fluency, vocabulary and comprehension than eventually create awareness of what learning strategies that should be implemented (Olviyanti, 2015).

\section{Phonics Implementation}

A phonics implementation research was conducted in Africa using the Mama Kelello method. In the research, it was found that the teacher will ask the students to guess the rhyming words form the words that they heard in the big book story book. It was further observed, that when students count the words that they copy onto their workbook so they won't intentionally mix the words. The researcher also found out how some sounds were practiced and repeated throughout the whole week and expectedly with different activities (Masello, 2014). Masello also added that there should be an emphasis on the integration of sound system in stories and other text that may develop the reading and writing skills. It was further found that teaching should be not be a one-way technique. It can either be in form of storytelling, songs, rhymes, 
dramatization, learning through play as well as questions and answers. This shows how teaching should be adaptable and diverse with different levels and learning style of learners. In relation, the use of phonics in the Hongkong education has spread widely in the schools' systems and the most used phonics instruction is using the explicit phonics instructions (Jia $\mathrm{Yu}, 2015)$. Explicit phonics instruction provides a sequential, systematic approach to instruction, practice, and feedback that guide students in the development of fluency skills (Desiree, 2016). Nevertheless, the phonics instructions were not as perfect as when no attention were made in teaching phonics to the English Second Language learning compare to the native speakers or English learners. It was also further found that the aspect of teaching English as a second language were not exposed to the English teachers with most of them lacks of vocabulary knowledge, language and grammar structure. This undoubtedly will lead to low language acquisition among the English as a Second Language learners and they will spend too much time to understand written text due to lack of vocabulary, structure, and knowledge (Jia Yu, 2015). Jia Yu continuously reported that the students could not read properly due to deficiency of phonics skills when identifying phonemes. Students who failed to decode the sounds of letters that form words when reading printed text will simply read the text without understanding what it meant and thus no new information can be use and this will interrupt the literacy skills among learners (Robyn, 2014). Due to that also, there is a misinterpretation of the most effective way of teaching literacy skills among English educators. Reading and writing were widely use to determine the literacy skills among language learners (Hamidah, 2014). However, finding an appropriate yet innovative strategy to develop and enhance children's English literacy is not an easy thing to be done (Ariati, 2018). Initiating the literacy skills at the early stage of communicating among children could be a complex development (Ariati, 2018). It is at this early stage that children should be exposed on the techniques of identifying letter sounds. However, it was further found that in the early language learning, language learners were having difficulties to decode the letters sounds. So, it is crucial for educators to know what techniques that should and could be use to teach the children to decode letter sounds. In Malaysia, phonics teaching was introduced in 2017 as part of the curriculum (KPM,2017). However, as stated by Napisah and Nadiah, there were lack of phonics knowledge among the English teachers based on previous studies of the readiness of the English language teachers in teaching phonics. They also stated in the research that the teachers who taught phonics were needing of extra training to teach phonics. The correct approach to teach phonics, the lack of knowledge of how to teach sounds of letters based on the Learning Standards in the curriculum and teaching strategies were among the teachers had faced when teaching phonics in classrooms (Nadiah \& Napisah 2015). The inability of both teachers and pupils in pronouncing the words, letters and phonemes, the teachers' unfamiliarity with phonics, the pupils' inability to blend and segment words, and also the interference of the pupils' mother tongue were also problems that teachers and learners had to encounter in the teaching and learning process were found in the same research. Therefore, utilizing an effective reading program, especially for early readers, is essential (Kellie, 2013). A large number of low-progress readers, especially when starting a reading, requires a more intensive intervention and different structures than normal students, where they need to learn to understand alphabetical codes and which specific and systematic teaching of phonics that has proven to be the most beneficial to be use with (Buckingham,2013; Lonigan, 2013). Hence, teachers and educators should choose the best strategy and overcome the problem and include phonics in their teaching of reading as a part of a strategy to improve the literacy among weak pupils. It is widely suggested that the teacher should improve or create strategy or technique in teaching reading (Olviyanti, 2015). 
Phonics Implementation: The Introduction of Jolly Phonics Blending Phonemes

Jolly Phonics teaches students to identify alphabets letter sounds using synthetic phonics. There are 32 letter sounds that are divided into 7 different groups. Each group will have six to seven different letter sounds. Not like the traditional teaching of phonics, students had to learn phonics base on the alphabetical order but in jolly phonics the learning starts form the easiest sounds to the hardest. This way students will be more comfortable especially the weak learners as they learn the phonemes beginning at the low level first. In complementing the Jolly Phonics method blending is introduce to combine the letter sounds together. Blending is a form of techniques to join the phonemes to form understood words. It can be a mix of different sets of sounds such as ' $t$ ' with ' $i n$ ' or ' $t$ ' with ' $o y$ '. Either way, blending involves the basic method of learning to read words. By combining both method in teaching phonics, Jolly Phonics Blending Phonemes can be a great alternative in introducing phonics to young readers. The ability to hear and separate individual sounds within a word (phonemic awareness), and then to blend those sounds into a word, is basic to reading and spelling. (Alvermann \& Earle, 2003; Bernhardt, 2011; Puteri, 2017).

Table 1: The Seven Groups of Jolly Phonic

\begin{tabular}{ll} 
Groups & Letters \\
\hline Group 1 & s a t i p n \\
Group 2 & c k e h r m d \\
Group 3 & g o u l f b \\
Group 4 & ai j oa ie ee or \\
Group 5 & z w ng v oo oo \\
Group 6 & y x ch sh th th \\
Group 7 & qu ou oi ue er ar \\
\hline
\end{tabular}

\section{Method}

\section{Introduction}

This research will determine the effectiveness of the Jolly Phonics Blending Phonemes to the Year 3 students that consists of 30 students in one school. The students are divided into two different groups of Experimental groups and the Control group which will be name as Group A and Group B. Group A (Experimental Group) will be introduced to the Jolly Phonics Blending Phonemes while the Group B (Control Group) will be taught using the traditional teaching of Phonics which uses the alphabetical order of phonemes. Both groups will have separated classroom teaching but will have the same teacher. This is to distinguish any uncontrollable variables such as the experience of the teacher teaching and the classroom environment. However, there will still be incontrollable variables from the students' side such as knowledge background, English language proficiency and fluency. That is why, the research will use the quasi-experimental research design to determine the results of this research.

\section{Research design}

This research will have three different stages that comprises of Pre-test, Post-Test, six months teaching session which uses the Jolly Phonics Blending Phonemes (Group A) and traditional Phonics teaching (Group B) and classroom observation that will be carried out during the 
teaching session. At the first stage, a pre-test text will be given to the students to read and in the text, new words will be introduced. These words will prescribe the students ability to recognize and pronounce unfamiliar words. This test will then be recorded as the early score for both groups and will be compared at the end of the research with the post-test results. The pre-test will also include a simple questionnaire with 5 basic questions. The questions are straight-forward and uses the simple English language structure to comprehend the thinking level of the Year 3 students and the same questionnaire will be given at the end of the teaching session for Group A and Group B to verify the levels of understanding before and after the 6 months teaching sessions.

For group A, the lesson plan will include the Jolly Phonics Blending Phonemes in each lesson plan. Each lesson plan will contain different group levels. However, if the students were not able to master certain levels of the Jolly Phonics table, the lesson or the phonemes will be retaught until they the students are able to master or identify the phonemes. The flow of the process is as shown in the Figure 1 below:

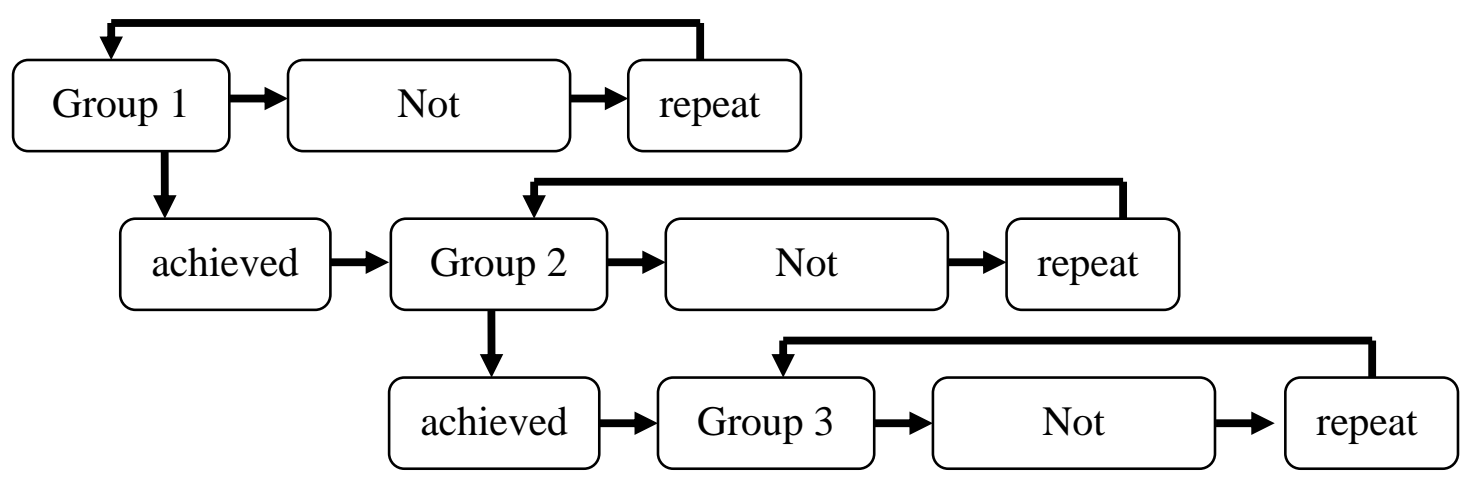

Figure 1: The Process Flow of Teaching Using Jolly Phonics

\section{Findings}

Jolly Phonics is a fun- systematic program designed for young or beginner learner to develop their reading and literacy skill (Araiti, 2017). Therefore, to teach pupils to master the skills of phonics, Jolly Phonics Blending Phonemes was chosen for this research. In the period of six months, pupils in Group A (Experimental Group) were exposed to the method of teaching using blending phonemes which consists of 7 levels of Jolly Phonics. In the research, it was found that there were significant changes in the scores compared to the pre-test for Group A and Group B. The changes were mostly on the phonics skills and the ability to read the same unfamiliar words that they had tried to read in the pre-test. In the post-test, pupils were already having the necessary skills to differentiate different types of letter sounds. By referring to the first research question of the ability of pupils being able to identify different types of letter sounds, pupils' phonics skills had increase from their previous lesson. However, this improvement only cater to Group A while Group B has not showed significant increase from their previous score.

Table 1.2 shows the mean scores and standard deviation for Group A. The table shows the difference before and after the implementation of Jolly Phonics Blending Phonemes for the experimental Group A. 


$\begin{aligned} & \text { Table 1.2: Frequency Mean Scores And Standard Deviation } \\
& \text { Different score data on the Pre-test and Post-test marks }\end{aligned}$
\begin{tabular}{llll}
\multicolumn{4}{c}{ for Group A } \\
\hline Test & Mean & $\mathrm{N}$ & Std.Dev. \\
Pre & 4.8 & 15 & 1.57 \\
Post & 6.6 & 15 & 2.20 \\
\hline
\end{tabular}

After taking the overall means scores from both Pre-test and Post-test, there is a big difference in the means scores after the Post-test with $x=6.6$ compared to the Pre-test with the mean scores of $x=4.8$. A difference of $x=1.8$. The standard deviations from the Post-test is $\sigma=$ 2.20 compared to the Pre-test with $\sigma=1.57$. There is significant increase in the score for the pupils.

Rebecca (2018), and Shultz \& Vouloumanos (2010) stated that, before young learners able to identify and pronounce any words, they have to find the sounds that are much more interesting to them than others. Teaching phonics involves a lot of practices and teachers' creativity to engage the pupils' interest in the lesson. Teachers should focus more on the pupils' interest rather than focussing on the curriculum. Interest plays important role in reading. Without interest, it is impossible to encourage students to read and try to comprehend the meaning of the text. Reading is a skill that every student needs to master in order to understand the text well (Liu, Nooreiny \& Melor, 2016). That is what Jolly Phonics intended to do. Pupils' are more occupied with learning the phonics structure because it involves the pupils' participations with songs and self-access-learning. The first phase of each lesson was introduced with Jolly Phonics songs and then, pupils learn the blending of phonemes. This pupils-centred teaching evolves around the pupils' experience in learning. As stated by Maimunah (2017), teaching and learning approaches for students need to shift from teacher-centred to student-centred learning with balance of knowledge, skills, and attitudes. This statement also correlates with Naning which stated that the 21st century classroom that was the focus of the KPM had spouse into the development of the pupils learning experience (Naning, 2016). In relation to that, same questionnaire that was given to the Group A and B in the post-test had spouse significant results that regarding the pupils' interest towards the Jolly Phonics Blending Phonemes in the Year 3 Primary EL. Chart 1.1 shows the outcomes for the pre-test and Chart 1.2 shows the outcomes for post-test for Group A. From Chart 1.1 indicates the pupils were not acknowledge with Phonics teaching at the early stage. In that survey, it was found at that $73.3 \%$ of the pupils did not know what is Phonics, and did not know why they had to learn phonics. Children (pupils) will try to make sense of what they are learning and forced of learning it (Steve, 2016). This is not what Jolly Phonics Blending Phonemes was meant for. Pupils should learn for fun and results shows that they are much interested in learning Phonics after six months. 
Chart 1.1: Pre-Test Questionnaire Of Group A

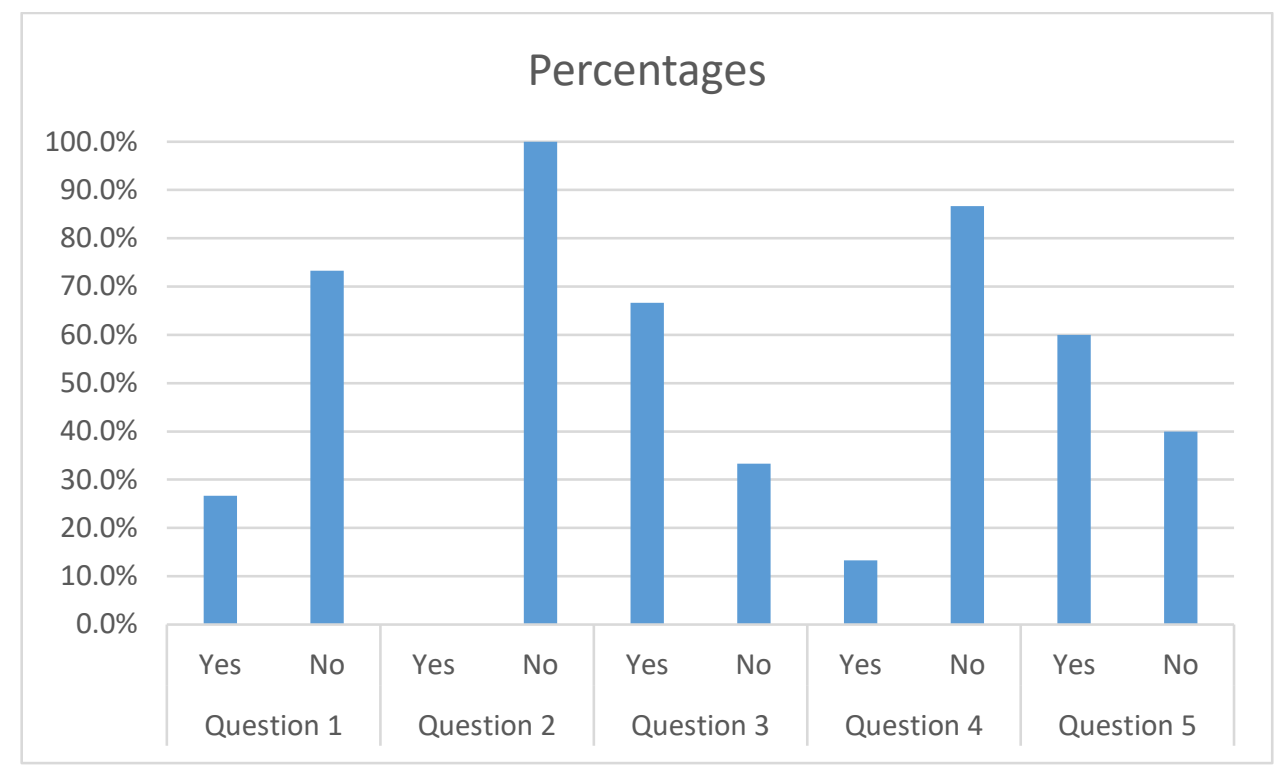

\section{Chart 1.2: Post-Test Questionnaire Of Group A}

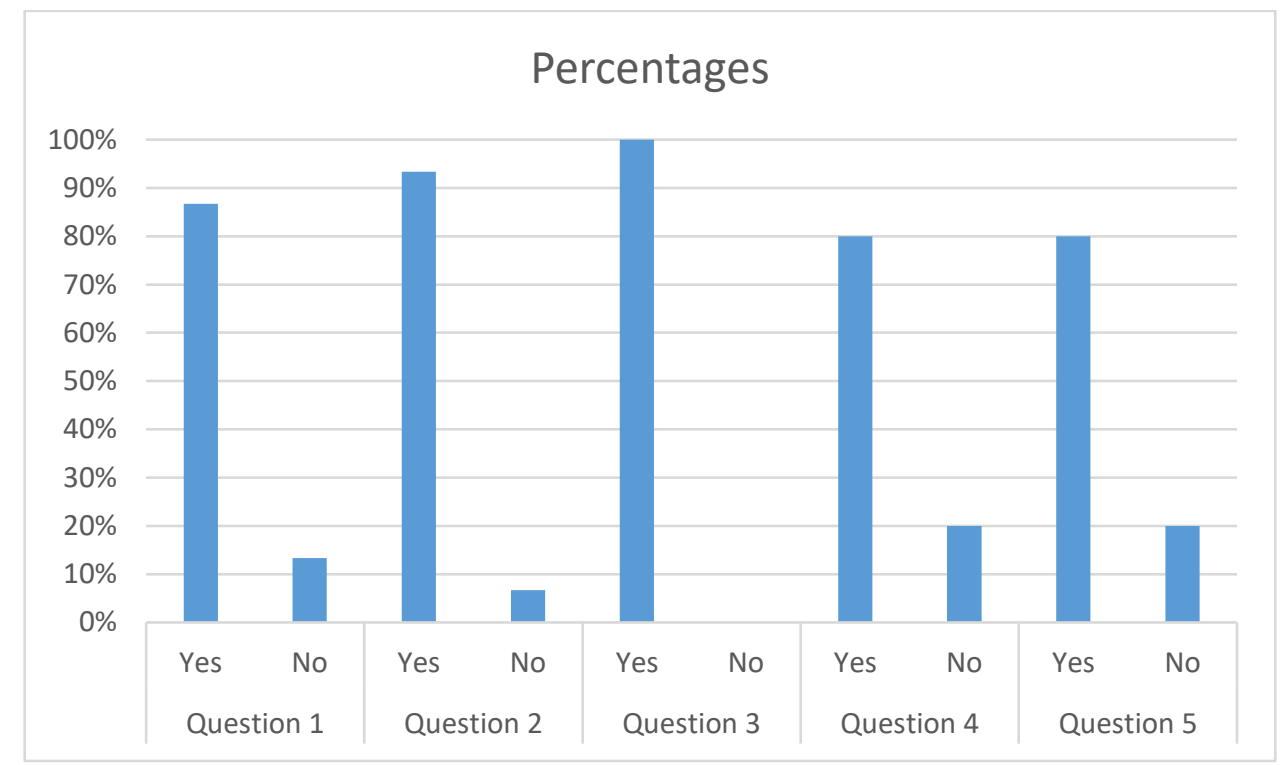

In Chart 1.3, Chart 1.4, shows how the pupils had developed from the previous knowledge of phonics skill. In the pre-test, only 7 pupils were able to get more than 6 or 7 marks and 8 pupils had 5 or lower marks. In the post-test, the total number of pupils who had 6 marks and above with the increase to 12 pupils who have $60 \%$ or above of total marks. Within the 12 pupils, 7 pupils have had 7 marks and one pupil had full mark. This clearly shows how the Jolly Phonics Blending Phonics method actually increase the pupils' skills in recognizing letter sounds. 
Chart 1.3: Pre-Test Percentages Of Correct Answers Based On 60\% For Group A Percentage of Correct Answers

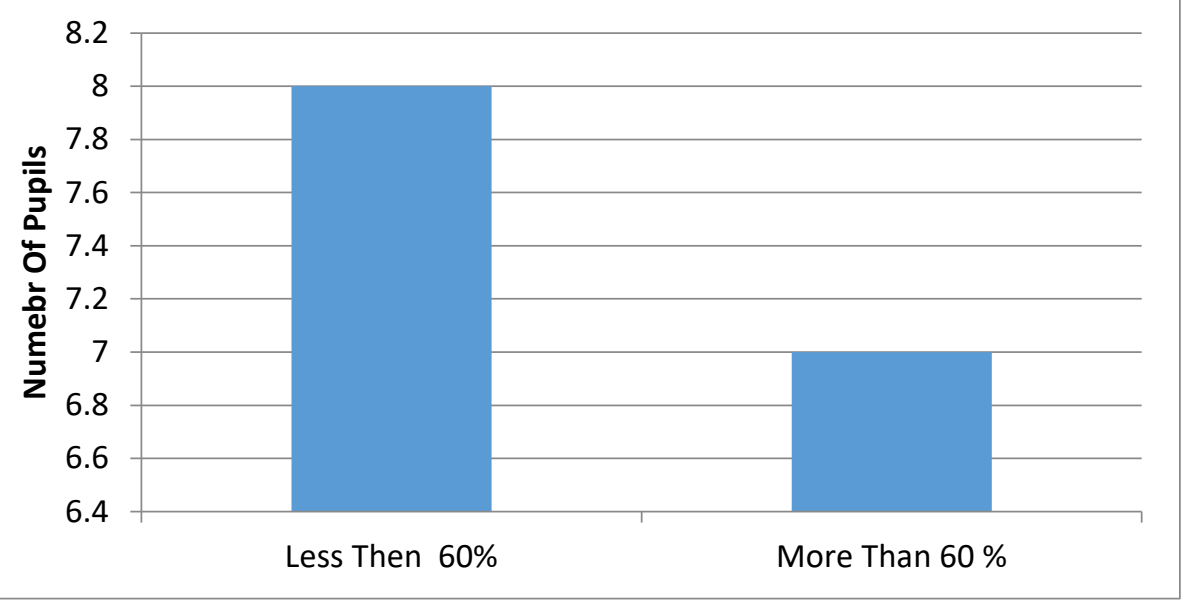

\section{Chart 1.4: Post-Test Percentages Of Correct Answers Based On 60\% For Group A}

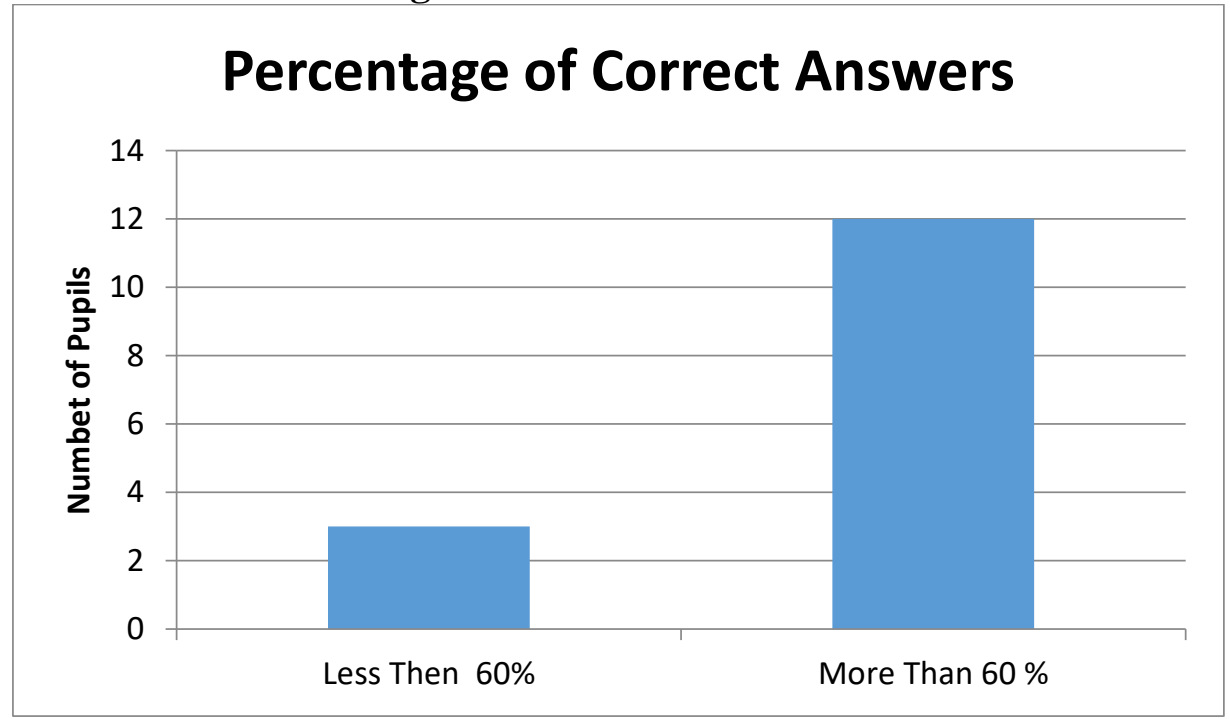

When the Jolly Phonics were introduced, pupils were having difficulties in blending the phonemes as they need to memorize most of the actions and differentiate each letter sounds with different actions either with hands, arms or other parts of the body. Jolly Phonics Blending Phonics does not require the pupils to memorize the gestures but they need to understand how each of the letter sounds related to one another and not by isolating them according to the alphabet arrangement. The effects when using the Jolly Phonics can be seen in Chart $\mathbf{1 . 5}$ and Chart 1.6 for Group A and B and Chart 1.7 and Chart 1.8 for Group A and B. 


\section{Chart 1.5: Pre-Test Questions By Numbers For Group A}

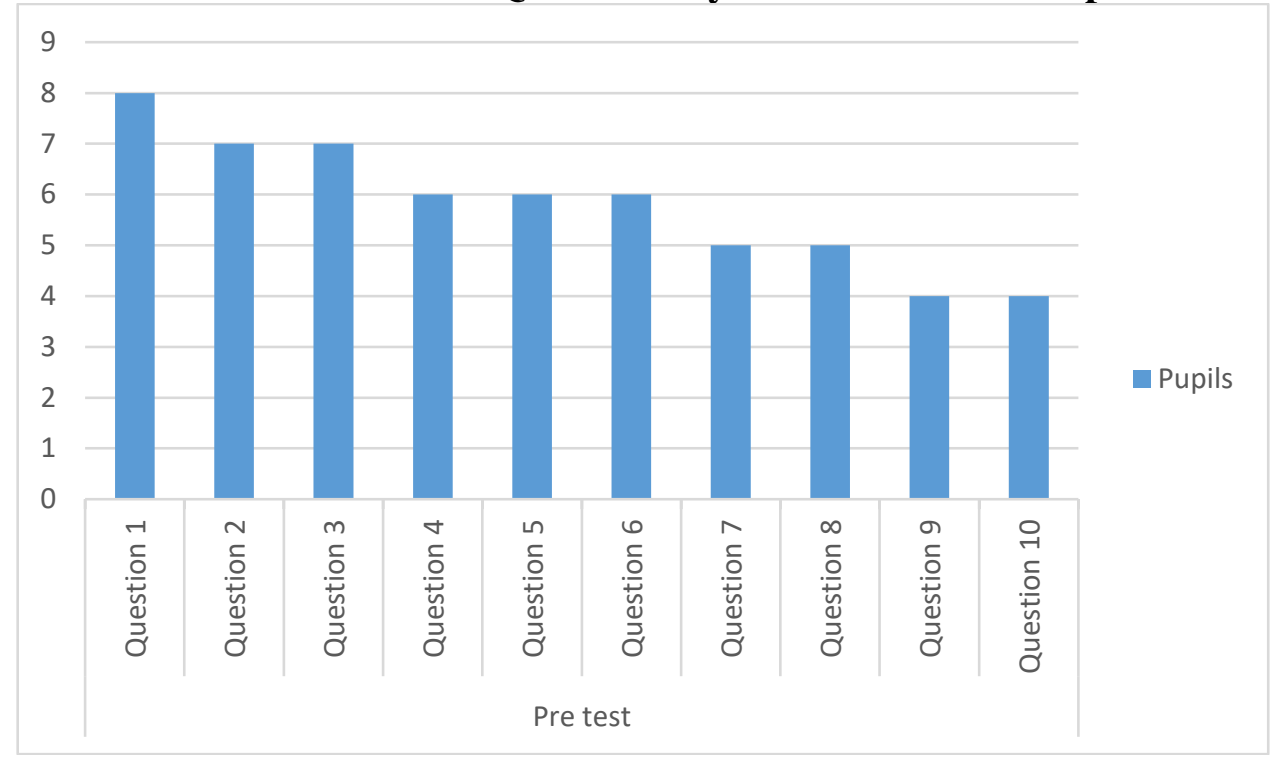

Chart 1.6: Pre-Test Questions By Numbers For Group B

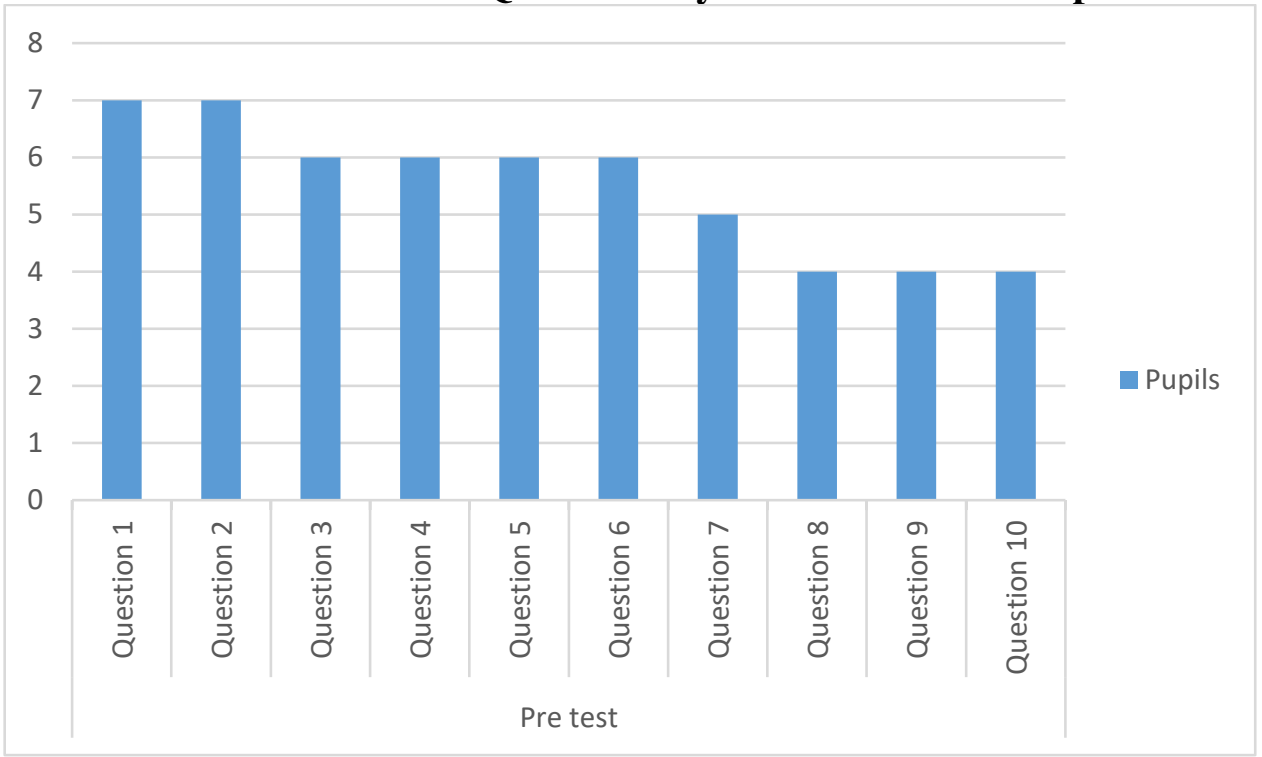

Each question is levelled from easy too hard to measure the pupil's ability to blend the letters. In Chart 1.5, only half or 53\% of the pupils were able to get the answer correct and the percentages decrease when the questions become harder with only $27 \%$ of the pupils or 4 of them were able to answer the questions correctly. This was quite alarming since being able to read requires the pupils to know how to blend the letter sounds. For Group B, the results were not as good or at par with Group A in the pre-test with 7 is the highest marks pupils were able to get with and only $27 \%$ of the pupils were able to get 4 marks while the $73 \%$ of the pupils got the questions wrong. In providing the researcher with consistent results, the same questions were given to the pupils in the post-test. In Chart 1.7, the results were quite fulfilling when $100 \%$ of the pupils were able to get question 1 and 2 correct and even though the percentages decrease from question 1 to 10 but compared to pre-test, the number of pupils had correct answer had increased; for example in the pre-test, only $40 \%$ of the pupils were able to get Question 4 to 6 correct and in the post test, the percentage had increase to 93\%. However, for 
Group B, the percentage did not increase in Chart $\mathbf{1 . 8}$ as pupils were not able to answer the same questions in the post-test. When referred to the research question, there are positive effects when using the Jolly Phonics Blending Phonemes to the Year 3 Primary EL pupils with the increase numbers of correct questions pupils in Group A were able to obtained.

\section{Chart 1.7: Post-Test Questions By Numbers For Group A}

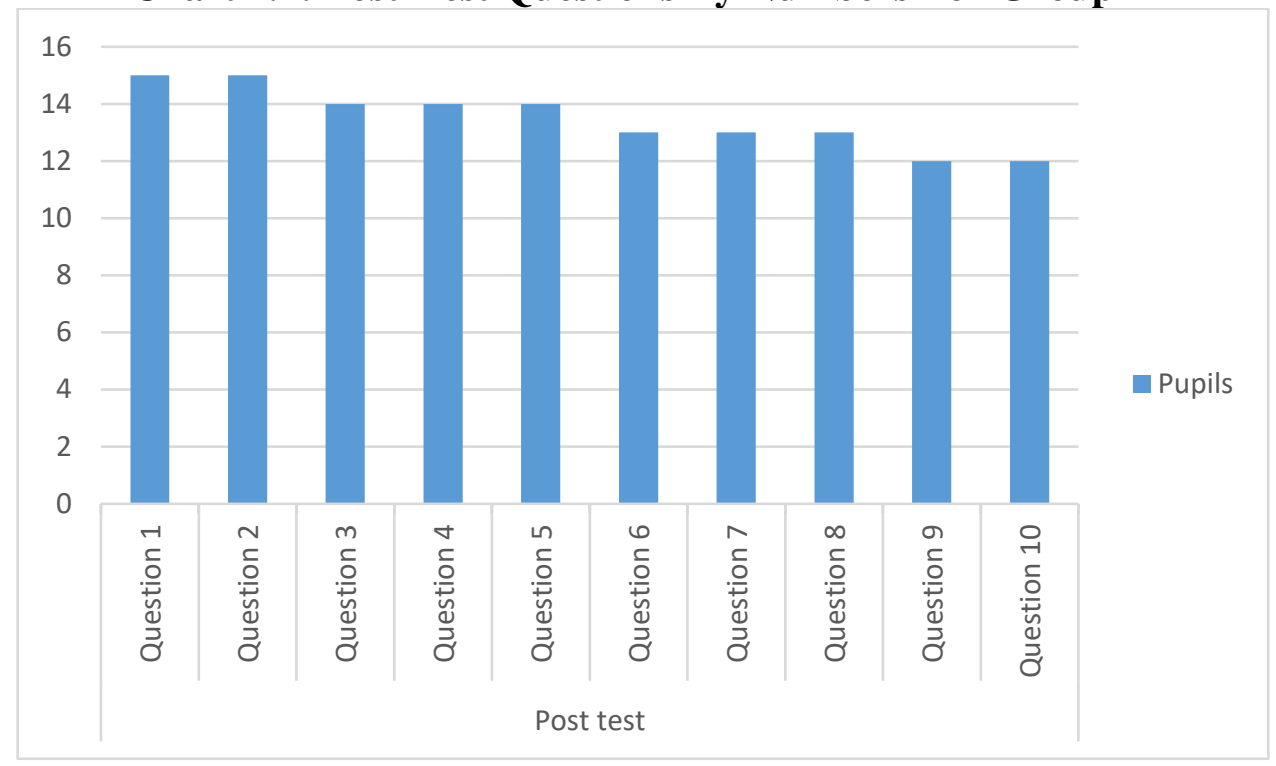

Chart 1.8: Post-Test Questions By Numbers For Group B

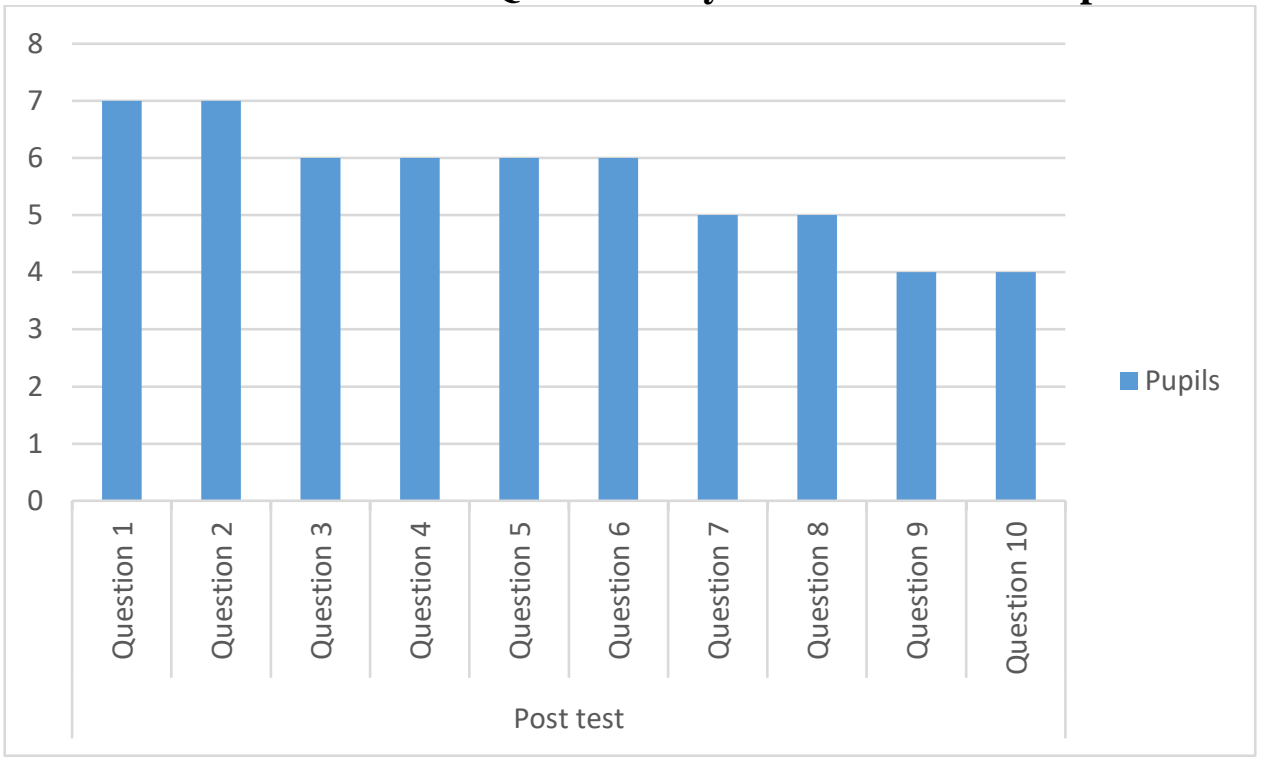

\section{Summary and Discussion}

This study examines the effectiveness of Jolly Phonics Blending Phonemes (JBPB) on 30 students in the re-urban area using tests and observations to determine their achievements and weaknesses within six months. It was found that, students had showed significant changes in the overall scores, interest and achievements. However, the experimental Group A (Experimental Group) had showed great results when compared to Group B (Control Group). Group A were able gain higher scores from the current tests and showed more interest in the Phonics lesson after the JPBP was introduced. This notable increase in the overall performance 
validated that when students are exposed to a new and engaging method, they will show interest and self-motivated. The key feature of JPBP is self-access learning where students were able to study and learn even after each lesson had ended encouraging them to improve overtime with less involvement by the teacher. JPBP can be beneficial to the Ministry of Education of Malaysia as new method that can be taught to teachers to improve the Phonics teaching. However, JPBP does involve a lot of time and effort for both parties where teachers have to work hard and focus on the teaching and observe students' performance because JPBP is a staged teaching. If students had missed or unable to achieve one stage or level of the Jolly Phonics table, they have to repeat until they are able to master to identify the phonemes and perhaps this problem can be studied in the near future exploring factors to improve the Jolly Phonics Blending Phonemes method. Nevertheless, Jolly Phonics Blending Phonemes does affect the performance of the Year 3 EL classroom learners and brought changes how to improve the overall reading skills.

\section{References}

Amanda, T. (2017). An Examination into the Instruction of the Alphabet During Preschool Years. Examination Instructions, 1(1), 1st ser.

Antonia, W., Md Yunus, M., \& Azlina, A. (2016). Students' Perception of using Games in the Teaching of Reading Skill. Education in the 21th Century: Responding to Current Issues.

Antilla, J. A. (2013). The Effects of Early Literacy Development on Academic Success In The Educational Setting And Implications For Educational Leaders And Teachers. The Effects of Early Literacy Development on Academic Success in The Educational Setting and Implications for Educational Leaders and Teachers, 1(1).

Ariati, N. P., Padmadewi, P. N., \& I Wayan, S. W. (2018). Jolly phonics: Effective strategy for enhancing children english literacy. Jolly Phonics: Effective Strategy for Enhancing Children English Literacy.

Desiree, G. E. (July 2016). The Impact of Explicit Phonics Instruction on the Fluency Rate of First Graders. 1(1), 1-38.

Glazzard, J. (2017). Assessing reading development through systematic synthetic phonics. English In Education,51(1), 44-57.

Hammond, M. (2016). Input Optimisation: Phonology and Morphology. Phonology and Morphology,33(3), 459-491.

Hamidah, Y, Fisher, R \& Rich, S. (2014). Revisiting English Language Learning among Malaysian Children. Revisiting English Language Learning among Malaysian Children,10(3).

Kellie, B. D. (2013). Use of Phonics Program with Early Childhood General Education and Special Education Students. Use of Phonics Program with Early Childhood General Education and Special Education Students, 1(1).

Lim, L. K., Md Yunus, M., \& Mohamed Amin, E. (March 2017). Build Me Up: Overcoming Writing Problems Among Pupils in A Rural Primary School in Belaga, Sarawak, Malaysia. Jurnal Pendidikan Humaniora, 5(1), 1-7.

Liu, C. L., Nooreiny, M., \& Md Yunus, M. (2016). Factors Affecting ESL Reading Comprehension of Malaysian Secondary School Students. Education in the 21th Century: Responding to Current Issues.

Maimunah, N., \& Hashimah, M. (Januari,2017). Peranan Guru Tingkatan Enam Dalam Membentuk Pelajar Terarah Kendiri Dan Meningkatkan Kemahiran Abad Ke-21. Jurnal Kurikulum \& Pengajaran Asia Pasifik, 5(1).

Masello, P. H. (2014). Introducing Beginning Reading Using Phonics Approach. Mediterranean Journal of Social Sciences, 5(10). 
Megan, G., Linda, C., Teresa, Y. C., Greg, L., \& Miriam, G. (2016). Developing Sound Skills for Reading: Teaching Phonological Awareness to Pre-schoolers With Hearing Loss. Developing Sound Skills for Reading: Teaching Phonological Awareness to Preschoolers with Hearing Loss, 1(1), 1st ser., 268-279.

Nadiah, A. Y., Napisah, K., \& Mariyatunnitha, S. (2015). Implementing the Teaching of Phonics in Malaysian Primary Schools. Implementing the Teaching of Phonics in Malaysian Primary Schools, 1(1).

Naning, W. T., Endang, F., \& Mauly, H. (2016). The Effectiveness of Using Phonics Instruction and Storybooks in English Reading Classes to Improve Student Participation. English Language Study, 11(1), 49-64.

Nasrawi Jia Yu, D. (2015). A case study on the use of phonics instruction, implicit and explicit, to help low proficiency ESL learners at primary level to develop proficiency and enjoyment in English reading. A Case Study on the Use of Phonics Instruction, Implicit and Explicit, to Help Low Proficiency ESL Learners at Primary Level to Develop Proficiency and Enjoyment in English Reading, 1(1).

Nasrawi, A., \& Al-Jamal, D. (2017). The effect of using jolly phonics on Jordanian first grade pupils' reading. International Online Journal of Education and Teaching (IOJET). The Effect of Using Jolly Phonics on Jordanian First Grade Pupils' Reading,4(2), 106-119.

Olviyanti, I., Rismaya, M., \& Zainal, A. (2015). An Analysis on The Ability Comprehending A Reading Text By the Sixth Year Students. An Analysis on The Ability Comprehending A Reading Text by The Sixth Year Students, 1(1).

Puteri Rohani, M., Faridah, Y., \& Zuraida, Z. (2017). Facilitating Reading Comprehension Among Esl Learners Using Graphic Organizers. Malaysian Journal of Elt Research, $13(1), 30-42$.

Rabindra, P. D. (2016). Implementing Phonics in Malaysia. International Journal of English Language Teaching and Linguistics, 1(1), 1-18.

Rebecca, T. (2018). What Research Tells Us About Reading Instruction. Psychological Science in the Public Interest, 19(1), 1-6.

Rachel, B. L. (2016). Influence of Motivation on Phonics Effectiveness. Influence of Motivation on Phonics Effectiveness, 1(1), 1-31.

Robyn, E. (2014). Phonics: Its place in the literacy story. Phonology and Morphology,1(1).

Steve, K. (2016, January 8). Why do we need to learn this? Retrieved September 9, 2018, from https://medium.com/@stevekrouse/why-do-we-need-to-learn-this-3ba1d42bd08a 